\title{
Parçalı ormanların yönetim sorunlarının değerlendirilmesi: Trabzon Orman İşletme Müdürlüğü örneği
} Evaluation of management problems of fragmented forests: A case study on Trabzon
Forest District Directorate

\author{
Nur DİKTAŞ BULUT ${ }^{1}$ \\ Cantürk GÜMÜŞ² \\ Uğur ER ${ }^{3}$ \\ Mehmet Ali SAYIN ${ }^{3}$ \\ Vildane GERÇEK ${ }^{1}$ \\ Hüseyin AYAZ2 ${ }^{2}$ iD \\ Necati ÇOLAK ${ }^{4}$ (DD
${ }^{1}$ Doğu Karadeniz Ormancılık Araştırma Enstitüsü Müdürlüğü, TRABZON
${ }^{2}$ Karadeniz Teknik Üniversitesi, Orman Fakültesi, TRABZON
${ }^{3}$ Trabzon Orman Bölge Müdürlüğü, TRABZON
${ }^{4}$ Ege Ormancılık Araştırma Enstitüsü Müdürlüğü, İZMIR

Sorumlu yazar (Corresponding author) Nur DİKTAŞ BULUT

nurdiktasbulut@ogm.gov.tr

Geliş tarihi (Received)

12.03.2019

Kabul Tarihi (Accepted)

08.05.2019

Atıf (To cite this article): DİKTAS BULUT, N GÜMÜS, C , ER, U , SAYIN, M , GERÇEK, V AYAZ, H , ÇOLAK, N . (2019). Parçalı ormanların yönetim sorunlarının değerlendirilmesi: Trabzon Orman İșletme Müdürlüğü örneği. Ormanc1lık Arastırma Dergisi, 6 (2), 177-191. DOI: https://doi.org/10.17568/ogmoad.538684

\begin{abstract}
Öz
Bu çalışma ile Trabzon Orman İşletme Müdürlüğü örneğinde parça11 ormanların yönetim sorunlarının belirlenmesi amaçlanmıştır. Bu kapsamda orman kaynaklarını yönetenlerin uygulamada karşılaştıkları teknik ve sosyal sorunlar tespit edilmiş, orman kaynakları ile iç içe yaşayan orman köylüsünün orman kaynaklarını kullanma durumu, beklentileri ve önerileri değerlendirilmiştir. Parçalı ormanların yönetimiyle ilgili beş ana sorun belirlenmiştir. Bunlar; parçalı ormanların kadastrosunun yapılmasındaki sorunlar, parçalı ormanların yönetimindeki sosyal sorunlar, parçalı ormanların planlanması aşamasındaki sorunlar, parçalı ormanlardaki ormancılık uygulamaları (koruma, ağaçlandırma, bakım, rehabilite vb.) açısından sorunlar ve parçalı ormanların korunmasındaki sorunlardır. Orman köylüsünün ormanlardan faydalanabilme noktasında beklentisi ise orman ürünlerine yönelik ihtiyaçlarının karşılanması (üretim amaçlı) olarak belirlenmiştir. Bu çalışma ile, parçalı ormanlara orman amenajman planı içerisinde farklı bir statü kazandırılarak, faydalanmanın yerel yönetimlere bırakılmasının uygun olabileceği değerlendirilmiştir.
\end{abstract}

Anahtar Kelimeler: Ormanlardan faydalanma, orman köylüsü, parçalı ormanlar, yönetim sorunları, Trabzon

\begin{abstract}
In this study, it is aimed to determine the management problems of fragmented forests in Trabzon Forest District Directorate. The technical and social problems faced by the managers of the forest resources were determined with the study. Similarly, the situation, expectations, and suggestions of forest villagers living with forest resources were evaluated. Five main problems related to the management of fragmented forests have been identified. These problems are (i) the cadaster of fragmented forests, (ii) social problems, (iii) the planning of fragmented forests, (iv) forestry practices (conservation, reforestation, maintenance, rehabilitation, etc.) and (v) the protection of fragmented forests. The expectation of forest villagers was determined as providing their forest product needs (for producing). With this study, it was considered that the fragmented forests should be given a different status in the forest management plan and the utilization of these forests should be left to local administrations.
\end{abstract}

Keywords: Fragmented forests, forest villager, management issues, Trabzon, utilizing forests 


\section{Giriş}

Küresel ölçekte olduğu gibi ülkemizde de nüfus artışının bir sonucu olarak tarımsal alanların genişlemesi, otoyolların, tren yollarının yapılması, barajlar ve diğer yapay göletler, enerji tesisleri, iletim hatları, ülke veya parsel sınırlarının canlı geçişini engellemek amaciyla yapılan yapılar, toplu konutlar, madencilik tesisleri, dere 1 slahı adı altında yapılan duvarlar gibi nedenlerle doğal alanlar giderek daha küçük parçalara bölünmektedir. Literatürde "habitat bölünmesi/parçalanması" olarak adland1rılan bu gelişmelerin birçok olumsuz sonucu ortaya çıkmaktadır (Deniz ve ark., 2006; Coşkun Hepcan, 2008; Williams ve Snyder, 2005).

Bilindiği gibi habitat; bir canlı türünün yaşadığı, saklandığ1, aranınca bulunabildiği, kısaca yaşamsal etkinliklerini sürdürmesine uygun koşulların bulunduğu alanı ifade etmektedir (Odum ve Barrett, 2005). Habitat parçalanması, geniş ve yapay engellerle çevrili olmayan canlı yaşam alanlarının yok edilmesi veya daha küçük ve çevreden soyutlanmış kalıntılara dönüşme sürecidir (Wilcove ve ark., 1986). Habitat bölünmesinin başta biyolojik çeşitlilik olmak üzere (Sala ve ark., 2000; Fahrig, 2003; Foley ve ark., 2005) türlerin popülasyon büyüklüğünün azalması (Andren, 1994), bitki popülasyonlarının genetik kompozisyonunun değişimi (Young ve ark., 1996), canlıların başka habitatlara göç etmesi ve oralarda yaşayan yerli türler ile rekabete girmesi ve canlı türlerinin tamamen yok olması gibi birçok ekolojik soruna yol açtığı bilinmektedir.

Kuşkusuz bu gelişmeler tüm kürede olduğu gibi ülkemizde de etkilerini giderek daha yoğun biçimde ortaya çıkaran bir tehdit durumundadır. Ormanların daha küçük parçalara bölünmesi özellikle sahip olduğu sosyoekonomik yapının da etkisiyle dağınık bir yerleşim desenine sahip olan Doğu Karadeniz Bölgesi'nde önemli bir sorun olarak görülmektedir.

$\mathrm{Bu}$ sorunlardan birisi de orman alanlarının yönetimi sorunudur. Habitat bölünmesinin ekolojik anlamda yol açtığı sorunlarla ilgili birçok çalışma ve makale vardır. Ancak çeşitli etkilerle küçük parçalara bölünen ormanlarda yürütülen ormancilık etkinlikleri de bundan etkilenmektedir. Bu çalışma ile Doğu Karadeniz Bölgesi'nin hemen hemen tam merkezinde yer alan Trabzon yöresi örneği ile küçük parçalara ayrılan ormanlık alanların yönetilmesiyle ilgili sorunlar ortaya konulmaya çalışılmıştır.

Çalışma bölgesinin coğrafi yapısıyla ilişkili olan kendine özgü dağınık yerleşim deseni ve geleneksel mülkiyet anlayışı sonucunda ormanların içerisine yerleşilmiş; ormanlık alanlar ise, yerleşim yerleri, tarım alanları ve meralar arasına s1kışmıştır. Nüfusun artmasıyla birlikte daha fazla tarım alanına ihtiyaç duyulmasının doğal bir sonucu olarak öteden beri tahrip edilen ormanların bütünlüğü bozulmuş, bütünlük hâlindeki ormanlar sadece yerleşim yerlerine uzak alanlarda korunabilmiştir. Bölgede orman, tarım ve yerleşim alanları iç içe geçmiş ve bölgeye özgü bir yaşam tarzı oluşmuştur. $\mathrm{Bu}$ yapı içerisinde, orman kaynakları sürekli baskı altında kalmış ve parçalı duruma dönüşmüştür. Son yıllarda yoğunluk kazanan kadastro çalışmaları sonucunda da özellikle yerleşim yerleri ve tarım alanları çevresinde alansal olarak daha küçük ölçekte, rasyonel olarak yönetilmesi zorluklar içeren orman parçaları hukuksal bir kimlik kazanmış ve çoğunlukla devlet ormanı olarak tescil edilmiştir. Buna karşın hâlen bu ormanlardan yararlanma alışkanlıkları sürmekte, sorun hukuksal olarak çözülmüş görünse de sosyolojik olarak devam etmektedir. Bu tür ormanlar, yöre halk1 tarafından kullanılamadığı gibi orman idarelerince işletilmesinde de sorunlar yaşanmaktadır. Benzer sahiplenmeler ve kayıt dışı geleneksel kullanımlar gelişmekte olan ülkelerde de görülmektedir (Yachkaschi, vd., 2008). Parçalı orman olarak ifade edilen bu ormanlardan mevcut yararlanma biçimi, orman kaynaklarını yönetme sorumluluğunda olanların ve yararlanma hakkı iddiasında bulunan veya bulunmayan orman köylülerinin bu ormanların yönetimiyle ilgili görüş ve yaklaşımlarının ortaya konması önem taşıyan bir konu hâline gelmiştir. Özellikle rasyonel orman işletmeciliği için parçalı ormanların yönetiminde karşılaşılan teknik ve sosyal sorunların boyutunun ortaya konulması, bölge ve dolayısıyla ülke ormancılığının gelişimi için önem taşımaktadır.

Ülkemizin ormanc1lik ilke ve hedefleri doğrultusunda bu çalışma ile Doğu Karadeniz Bölgesi'ndeki parçalı ormanların yönetim sorunlarının belirlenmesi amaciyla orman kaynaklarını yönetenlerin uygulamada karşılaştıklar1 teknik ve sosyal sorunlar tespit edilmiş, orman kaynakları ile iç içe yaşayan orman köylüsünün orman kaynaklarını kullanma durumu, beklentileri ve önerileri değerlendirilmiştir. Doğu Karadeniz Bölgesi'nin sahil kesimi bandındaki ormanlarda yaşanan sorunlar, tarımsal yapı çeşitliliği nedeniyle nitelik olarak bölgenin tamamı için homojen bir özellik göstermemektedir. Bununla birlikte geliştirilecek çözüm önerilerinin değişiklik göstermeyeceği düşüncesinden hareketle, çalışmanın sadece belirli bir bölgede yoğunlaştırılması yeterli görülmüştür. Bu nedenle çalışma bölgesi olarak ulaşım kolaylığı, çalışma giderlerinin azaltılması, orman kadastrosu çalışmalarının önemli ölçüde sonuçlan- 
mış olması gibi nedenlerle, Trabzon Orman İşletme Müdürlüğü sorumluluk alanı seçilmiştir.

\section{Materyal ve Yöntem}

\subsection{Materyal}

Çalışma ile Doğu Karadeniz Bölgesi’nin tamamında görülen ormanların parçalılık durumu, pilot alan olarak seçilen Trabzon Orman İşletme Müdürlüğüne bağlı beş orman işletme şefliğinin (Akçaabat, Düzköy, Şalpazarı, Tonya ve Vakfikebir) sorumluluk alanında incelenmiştir. Çalışmada, Trabzon Orman İşletme Müdürlüğü ve bağlı şefliklerinin resmi kayıtları, grup ve bireysel görüşmelerde kullanılan anket formları ve istatistik programları gibi materyallerden yararlanılmıştır.

\subsection{1. Çalışma alanının tanıtımı}

Trabzon Orman İşletme Müdürlüğü, faaliyetlerine ilk olarak 20.09.1943 tarihinde Revir Amirliği olarak başlamıştır. Daha sonraki yıllarda Of, Sürmene, Çaykara ve Araklı ilçelerini de bünyesine alarak Sürmene Revir Amirliği adı altında hizmet vermiş; 1948 yılında ise Trabzon Orman İşletme
Müdürlüğü adı altında şekillenmiştir. 24.02.1951 tarihinde Trabzon Orman Bölge Müdürlüğünün (OBM) kurulması ile İşletme Müdürlügü bu birim kapsamına girmiştir. 1967'de Sürmene ve Maçka Orman İşletme Müdürlüklerinden ayrılarak Trabzon Orman İşletme Müdürlügüunün bugünkü sınırları belirlenmiştir. Hâlen merkez ilçe, Akçaabat, Düzköy, Çarşıbaşı-Vakfıkebir, Tonya, Şalpazarı Beşikdüzü ilçelerini yönetim sınırları açısından kapsayacak şekilde hizmet vermektedir. Orman İşletme Müdürlüğüne bağlı şeflikler; Akçaabat, Düzköy, Şalpazarı, Tonya, Trabzon ve Vakfıkebir Şeflikleridir. Trabzon Orman İşletme Müdürlüğünün doğusu Sürmene ve Maçka Orman İşletme Müdürlüğü; batısı Giresun Orman Bölge Müdürlüğü ve Tirebolu Orman İşletme Şefliği; kuzeyi Karadeniz; güneyi Torul ve Maçka Orman İşletme Müdürlükleridir (Anonim, 2016).

\subsubsection{Orman varlığı}

Trabzon Orman İşletme Müdürlüğünün genel alanı 133.243,5 hektardır (ha). 58.595,5 ha orman alanında 48.168 ha verimli, 10427,3 ha bozuk orman alanıdır. Ormanlık alanın genel alana oranı \%44'tür (Tablo 1).

Tablo 1. Çalışma alanı orman varlığı*

Table 1. Forest asset in the area

\begin{tabular}{lccccc}
\hline \multicolumn{1}{c}{ Şeflik adi } & $\begin{array}{c}\text { Verimli Orman } \\
\text { Alanı (ha) }\end{array}$ & $\begin{array}{c}\text { Bozuk orman } \\
\text { alanı (ha) }\end{array}$ & $\begin{array}{c}\text { Toplam orman } \\
\text { alanı (ha) }\end{array}$ & $\begin{array}{c}\text { Ormansız alan } \\
\text { (ha) }\end{array}$ & $\begin{array}{c}\text { Genel alan } \\
\text { (ha) }\end{array}$ \\
\hline Akçaabat & $11.783,40$ & $1.393,00$ & $13.176,40$ & $19.150,90$ & $32.327,30$ \\
Düzköy & $6.919,30$ & $1.894,20$ & $8.813,50$ & $10.070,20$ & $18.883,70$ \\
Şalpazarı & $10.884,40$ & $2.855,40$ & $13.739,80$ & $12.150,50$ & $25.890,30$ \\
Tonya & $10.297,80$ & $2.291,80$ & $12.589,60$ & $8.057,90$ & $20.647,50$ \\
Merkez & 766,8 & 838,6 & $1.605,40$ & $12.165,90$ & $13.771,30$ \\
Vakfikebir & $7.516,30$ & $1.154,30$ & $8.670,60$ & $13.052,80$ & $21.723,40$ \\
\hline Toplam & $48.168,00$ & $10.427,30$ & $58.595,30$ & $74.648,20$ & $133.243,50$ \\
\hline${ }^{*}$ Trabzon OiM Resmi Kayitlarl (Anonim, 2016)
\end{tabular}

2.1.3. 6831 sayılı Orman Yasası kapsamında 31. ve 32. madde köyleri

Trabzon İlinde 06/12/2012 tarih ve 28489 say111 Resmi Gazete'de yayımlanan 6360 sayılı Yasa ile aynı adla büyükşehir belediyesi kurulmuştur. Trabzon ilinde, Trabzon Belediyesinin mahalleleri merkez olmak üzere, Trabzon merkez ilçe sınırları içerisindeki köyler ile belediyelerden oluşan Ortahisar ilçesi ve aynı adla belediye kurulmuştur (Anonim, 2012). Çalışmada konunun daha iyi anlaşılması amacıyla "mahalle" yerine yine "köy" ismi kullanılmıştır. Büyükşehir ve imar durumu gibi mevzuat değişikliklerinde orman köylülerine orman kanunu ile verilen haklar korunmaktadır.

Trabzon Orman İşletme Müdürlüğüne bağlı şefliklerin yönetsel sınırları içinde kalan 6831 sayılı Orman Yasası'nın 31. ve 32. maddesi kapsamındaki köylerinin (mahallelerin) sayıları aşağıdaki tabloda verilmiştir (Tablo 2).

Çalışma alanında toplam 251 köy (mahalle) olup, bunların 76'sı 31. madde, 89'u 32. madde köyüdür.

\subsection{Yöntem}

Parçalı ormanların yönetsel sorunlarının belirlenmesi amacıyla çalışmada örnek olay araştırması 
Tablo 2. 6831 say1lı Orman Yasas1 31. ve 32. madde köyleri**

Table 2. The villages within the scope of Forest Law No. 6831 Articles 31 and 32

\begin{tabular}{ccccc}
\hline Şefliği & $\begin{array}{c}\text { 31. Madde köyü } \\
\text { (adet) }\end{array}$ & $\begin{array}{c}\text { 32. Madde köyü } \\
\text { (adet) }\end{array}$ & $\begin{array}{c}\text { Diğer köyler } \\
\text { (adet) }\end{array}$ & $\begin{array}{c}\text { Köy (mahalle) } \\
\text { toplamı }\end{array}$ \\
\hline Akçaabat & 33 & 28 & 12 & 73 \\
Düzköy & 14 & - & 12 & 26 \\
Şalpazarı & 20 & 23 & 21 & 64 \\
Tonya & 9 & 6 & 6 & 21 \\
Vakfıkebir & - & 32 & 35 & 67 \\
Toplam & 76 & 89 & 86 & 251 \\
${ }^{* *}$ Trabzon OIM Resmi Kayttlarl (Anonim, 2016) & & &
\end{tabular}

yöntemi kullanılmıştır. Örnek olay araştırması yöntemi; "bir veya birkaç olayın derinlemesine incelenmesi (Bozgeyikli, 2013)" ya da "özel bir toplumsal grup hakkında belgelere dayalı bilgi toplama ve yorumlama (Arslanoğlu, 2016)" şeklinde tanımlanmaktadır.

Çalışmada örnek olay araştırması yöntemi üç aşamalı olarak gerçekleştirilmiştir. Bunlar;

- Grup (uzman) görüşmesi ve içerik analizi,

- Bireysel görüşme (ilgi grupları ve orman köylüsü anketi) ve

- Değerlendirmedir.

\subsubsection{Grup (Uzman) görüşmesi ve içerik analizi}

\subsubsection{Grup (Uzman) görüşmesi}

Trabzon Orman İşletme Müdürlüğünün yönetsel sınırları içerisindeki parçalı ormanların yönetim sorunlarının belirlenmesi, konu ile ilgili genel bir değerlendirilme yapılması ve anket uygulamalarında yöneltilecek soruların içeriğinin belirlenmesi amaciyla grup görüşmesi gerçekleştirilmiştir.

Grup görüşmesi; ormancılık araştırma enstitüsü müdürü (1), araştırma uzmanları (3), Trabzon Orman Bölge Müdürlüğünde görev yapan orman bölge müdür yardımcıları (2), şube müdürleri (6), işletme müdürleri (2), kadastro komisyon başkanları (3), amenajman heyet başkanları ve deneticisi (3), başmühendisler (4) ve işletme şefi (1) olmak üzere toplam 25 kişinin katılımıyla gerçekleștirilmiştir.

Katılımcılara öncelikle araştırmanın kapsamı ve amacı ile ilgili bilgiler verilmiş ve Doğu Karadeniz Bölgesi'ndeki ormancıllk faaliyetlerinde karş1laşılan teknik, sosyal ve yönetsel sorunlar üzerinde değerlendirmelerde bulunulmuştur. Grup görüşmesinde sağlanan bilgiler içerik analizi ile değerlendirilerek ilgi grubuna (OGM çalışanları) ve orman köylüsüne yönelik anket formları hazırlanmıştır

\section{İçerik analizi}

Grup görüşmesinde elde edilen veriler dört aşamada analiz edilmiştir.

- Verilerin kodlanması

- Temaların bulunması (tematik kodlama)

- Kodların ve temaların düzenlenmes

- Bulguların tanımlanması ve değerlendirme

Grup görüşmesinde elde edilen ortak konular değerlendirilerek ormanların yönetim sorunlarıyla ilgili beş veri kodu oluşturulmuştur. Ortaya çıkan kodlarda benzerlik/farklılık gösteren konular sentezlenerek tematik bir kodlama yapılmış ve beş veri koduna ait dörderli tema seti oluşturulmuştur. Grup görüşmesinde elde edilen beş kod ve dörderli tema seti, anket uygulamalarında ve istatistiksel analizlerde kullanılmak üzere düzenlenerek tablo hâline getirilmiştir. Bulguların tanımlanması ve yorumlama aşamasında ise istatistiksel veriler elde edilmiş ve beş veri kodu ve dörderli veri setiyle ilgili değerlendirmeler yapılmıştır.

\subsubsection{Bireysel görüşme (İlgi grupları ve orman köylüsü anketi)}

\subsubsection{1. İlgi grubuna yönelik anketler}

Parçalı ormanların yönetim sorunlarının belirlenmesi ve grup görüşmesinde elde edilen veri setlerinin önem sirasının ortaya konulması amac1yla orman mühendisleriyle anket uygulaması yapılmıştır. Hedef kitle olarak Trabzon Orman Bölge Müdürlüğüne bağlı orman işletme müdürlüklerinde görev yapan işletme müdürleri, işletme şefleri, kadastro komisyon üyeleri, amenajman heyeti üyeleri ve mühendisler seçilmiștir. Örneklem büyüklüğü belirlenmemiş ve tam alan örnekleme yapılmış olup tüm hedef kitleyle anket uygulaması 
yapılmıştır. Anketler açık ve kapalı uçlu soru tiplerinden oluşmaktadır. İlgi gruplarıyla toplam 66 anket uygulaması yapılmıştır.

\subsubsection{Orman köylüsüne yönelik anketler}

Çalışma alanındaki köylülerin ormanlardan yararlanma şeklini, karşılaştıkları sorunları ve beklentilerini belirlemek amaciyla anket uygulaması yapılmıştır. Anket uygulamasına başlamadan önce örneklem genişliğinin belirlenmesi önemlidir. Çok geniş bir örneklemle çalışmak para, zaman ve emek kaybına neden olabilir. Çok küçük bir örneklemle çalışıldığında ise, örneklemden yapılacak tahminler gerçeği ortaya koymayabilir (Çıng1, 1994). Hedef kitle olarak Trabzon Orman İşletme Müdürlüğünün yönetsel sınırları içerisinde yaşayan orman köylüleri seçilmiştir. Uygulanacak anket sayısının belirlenmesinde aşağıdaki formül (1) kullanılmıştır (Daşdemir, 2016; Orhunbilge, 2000);

$$
n \geq \frac{N x Z^{2} x p x q}{N x D^{2}+Z^{2} x p x q}
$$

N: Toplum Büyüklüğü (243.321 kişi), Z: Güven Katsayısı (\% 95'lik güven düzeyi için 1,96), p: Ölçülmek istenen büyüklügüun ana kütlede bulunma oranı $(p=0,5)$, q: Ölçülmek istenen büyüklüğün ana kütlede bulunmama oranı $(q=1-p)(q=0,5)$, D: Kabul edilen örnekleme hatası $(\mathrm{D}=0,05), \mathrm{n}$ : Örnek büyüklüğü

$$
n \geq \frac{243321 \times 1,96^{2} \times 0,5 \times 0,5}{243321 \times 0,05^{2}+1.96^{2} \times 0,5 \times 0,5} \Rightarrow n \geq 384
$$

kişiyle anket

Anketler açık ve kapalı uçlu soru tiplerinden oluşmaktadır. Çalışmada 387 orman köylüsüyle anket uygulaması yapılmıştır.

\subsubsection{Değerlendirme}

Anketlerin değerlendirilmesinde yüzde yöntemi, betimleyici istatistikler (aritmetik ortalama, standart sapma vb.) ve ki-kare testi (Daşdemir, 2016) kullanılmıştır.

\section{Bulgular}

\section{1. İçerik Analizi}

\subsubsection{Yönetim sorunlarının gruplandırılması}

25 kişiden oluşan uzman grup ile yapılan görüşmede ormanların yönetimiyle ilgili birçok sorun gündeme gelmiştir. Grup görüşmesinde elde edilen ortak konular değerlendirilerek parçalı ormanların yönetimiyle ilgili beş veri kodu oluşturulmuştur. Oluşturulan veri kodları;

Kad: Parçalı ormanların kadastrosunun yapılmasindaki sorunlar

Sos: Parçalı ormanların yönetimindeki sosyal sorunlar

Pln: Parçalı ormanların planlanması aşamasındaki sorunlar

Oru: Parçalı ormanlardaki ormancılık uygulamaları (koruma, ağaçlandırma, bakım, rehabilite vb.) açısından sorunlar

Kor: Parçalı ormanların korunmasındaki sorunlar şeklindedir.

\subsubsection{Yönetim sorunlarına ait temalar}

Grup görüşmesinde, ormanların yönetim sorunları belirlendikten sonra her bir sorun ayrı ayrı ele alınmıştır. Veri kodlarında benzerlik/farklılık gösteren konular sentezlenerek tematik bir kodlama yapılmış ve beş veri koduna ait dörderli tema seti oluşturulmuştur. Düzenlenen veri kodları ve tema seti aşağıdaki tablolarda (Tablo 3, 4, 5, 6, 7) verilmiştir.

\subsection{Orman kaynakları yöneticilerinin yönetim sorunlarına yaklaşımları}

Çalışmada "ilgi grubu" olarak adlandırılan orman mühendislerine yönelik toplam 66 kişiyle anket uygulaması gerçekleştirilmiştir. Ankette katılımcıların grup görüşmesiyle belirlenen yönetim sorunlarına ilişkin veri setlerini değerlendirmeleri istenmiştir. Ayrıca kişisel ve mesleki özellikler ve ormanların yönetim sorunlarıyla ilgili çözüm önerileri belirlenmiştir.

\subsubsection{Kişisel ve mesleki özellikler}

İlgi grubuna yönelik anket uygulamasında, katılımcıların öncelikle cinsiyet, yaş, eğitim düzeyi, görevi ve meslekteki çalışma süresinin belirlenmesine çalışılmıştır.

İlgi grubundan ankete katılanların \%93,9’ u erkek, $\% 6,1$ 'i kadındır.

Ankete katılanların öğrenim düzeyi incelendiğinde; \%87,9'unun lisans, \%12,1'inin ise yüksek lisans derecesine sahip olduğu görülmüştür.

Ankete katılan ilgi grubunun Trabzon Orman Bölge Müdürlüğündeki görev dağılımı Tablo 8'de verilmiştir.

İlgi grubunun görev süreleri incelendiğinde, 
Tablo 3. Parçalı ormanların kadastrosunun yapılmasındaki sorunlar Table 3. Problems in the cadastre of fragmented forests

\begin{tabular}{|c|c|c|c|}
\hline Veri ad 1 & $\begin{array}{l}\text { Veri } \\
\text { kodu }\end{array}$ & Tema & $\begin{array}{c}\text { Tematik } \\
\text { kod }\end{array}$ \\
\hline \multirow{4}{*}{$\begin{array}{l}\text { Parçalı ormanla- } \\
\text { rın kadastrosu- } \\
\text { nun yapılmasın- } \\
\text { daki sorunlar }\end{array}$} & \multirow{4}{*}{$\mathrm{Kad}$} & $\begin{array}{l}4785 \text { sayılı Devletleştirme Yasası'nın halen yürürlükte olması nedeniyle, } \\
\text { vatandaşa ait tapuların geçerliliğinin tartışmalı hale gelmesi }\end{array}$ & $\operatorname{Kad}_{1}$ \\
\hline & & $\begin{array}{l}\text { Vatandaşa ait tapuların vasıf, alan, sınır vb. bakımından fiili duruma uy- } \\
\text { maması ve dolayısıyla sahiplilik iddialarını destekleyebilecek geçerli bilgi } \\
\text { ve belgelerin olmaması nedeniyle, parçalı ormanların devlet ormanı ola- } \\
\text { rak tescil edilmesi }\end{array}$ & $\mathrm{Kad}_{2}$ \\
\hline & & $\begin{array}{l}\text { Mevzuat gereğince; orman kadastro komisyonlarının parçalı ormanları } \\
\text { özel orman vasfı ile tespit edememesi }\end{array}$ & $\mathrm{Kad}_{3}$ \\
\hline & & $\begin{array}{l}\text { Orman kadastro komisyonlarınca yapılan 2/B maddesi uygulamaları so- } \\
\text { nucunda ormanların daha parçalı hale gelmesi }\end{array}$ & $\mathrm{Kad}_{4}$ \\
\hline
\end{tabular}

Tablo 4. Parçalı ormanların yönetimindeki sosyal sorunlar

Table 4. Social problems in the management of fragmented forests

\begin{tabular}{|c|c|c|c|}
\hline Veri ad 1 & $\begin{array}{l}\text { Veri } \\
\text { kodu }\end{array}$ & Tema & $\begin{array}{c}\text { Tematik } \\
\text { kod }\end{array}$ \\
\hline \multirow{4}{*}{$\begin{array}{l}\text { Parçalı orman- } \\
\text { ların yöneti- } \\
\text { mindeki sosyal } \\
\text { sorunlar }\end{array}$} & \multirow{4}{*}{ Sos } & $\begin{array}{l}\text { Kesinleşmiş orman kadastrosuna rağmen parçalı ormanlar üzerindeki sa- } \\
\text { hiplilik iddialarının devam etmesi }\end{array}$ & $\operatorname{Sos}_{1}$ \\
\hline & & $\begin{array}{l}\text { Bireysel ya da toplu olarak vatandaşların parçalı ormanlardan yapılacak } \\
\text { ormancılık uygulamalarına (bakım, gençleştirme, rehabilitasyon, üretim } \\
\text { vb.) engel olması }\end{array}$ & $\mathrm{SoS}_{2}$ \\
\hline & & $\begin{array}{l}\text { Mevzuatın değişeceği ve mülkiyetinin vatandaşa geçeceği beklentisiyle } \\
\text { parçalı ormanların tahrip edilmesi }\end{array}$ & $\mathrm{Sos}_{3}$ \\
\hline & & $\begin{array}{l}\text { Yöreye özgü geleneksel orman ve ormancılık algısından dolayı parçalı } \\
\text { ormanların orman köylüsü tarafından orman olarak algılanmaması }\end{array}$ & $\mathrm{Sos}_{4}$ \\
\hline
\end{tabular}

Tablo 5. Parçalı ormanların planlanması aşamasındaki sorunlar

Table 5. Problems in the planning of fragmented forests

\begin{tabular}{lrlc}
\hline \multicolumn{1}{c}{ Veri adı } & $\begin{array}{c}\text { Veri } \\
\text { kodu }\end{array}$ & \multicolumn{1}{c}{ Tema } & $\begin{array}{c}\text { Tematik } \\
\text { kod }\end{array}$ \\
\hline & & $\begin{array}{l}\text { Amenajman planlarının yapılması sürecinde, kadastro altlıklarının kulla- } \\
\text { nılmamasından kaynaklanan sınır uyuşmazlıkları }\end{array}$ & $\operatorname{Pln}_{1}$ \\
$\begin{array}{l}\text { Parçalı ormanla- } \\
\text { rın planlanması }\end{array}$ & & $\begin{array}{l}\text { Parçalı ormanların fonksiyonlarına ve işletme amaçlarına karar verilme- } \\
\text { aşamasındaki }\end{array}$ & $P_{2}$ \\
sorunlar & Plndeki zorluklar & $\begin{array}{l}\text { Plan kararlarının yöre halkı ve diğer paydaşların katılımıyla alınmasın- } \\
\text { daki zorluklar }\end{array}$ & $\operatorname{Pln}_{3}$ \\
& & Parçalı ormanların envanterinin yapılmasındaki zorluklar & $\operatorname{Pln}_{4}$ \\
\hline
\end{tabular}

Tablo 6. Parçalı ormanlardaki ormancılık uygulamaları açısından sorunlar Table 6. Problems in forestry practices in fragmented forests

\begin{tabular}{|c|c|c|c|}
\hline Veri adi & $\begin{array}{l}\text { Veri } \\
\text { kodu }\end{array}$ & Tema & $\begin{array}{l}\text { Tematik } \\
\text { kod }\end{array}$ \\
\hline \multirow{4}{*}{$\begin{array}{l}\text { Parçalı ormanlardaki } \\
\text { ormancılık uygu- } \\
\text { lamaları (koruma, } \\
\text { ağaçlandırma,bakım, } \\
\text { rehabilite vb.) açısın- } \\
\text { dan sorunlar }\end{array}$} & \multirow{4}{*}{ Oru } & $\begin{array}{l}\text { Parçalı ormanlarda bakım ve gençleştirme çalışmalarının yapılmasın- } \\
\text { daki zorluklar }\end{array}$ & $\mathrm{Oru}_{1}$ \\
\hline & & $\begin{array}{l}\text { Parçalı ormanların amenajman planlarında yıllık bakım uygulamaları- } \\
\text { na dâhil edilmemesi }\end{array}$ & $\mathrm{Oru}_{2}$ \\
\hline & & $\begin{array}{l}\text { Küçük alanlarda çalışmanın ekonomik olmayacağı düşüncesiyle, parça- } \\
\text { lı ormanların rehabilitasyon çalışmalarına dâhil edilmemesi }\end{array}$ & $\mathrm{Oru}_{3}$ \\
\hline & & $\begin{array}{l}\text { Parçalı ormanlara; devrik, kırık, böcek zararı gibi biyotik ve abiyotik } \\
\text { faktörlerden kaynaklanan olağanüstü durumlarda bakım yapılamaması }\end{array}$ & $\mathrm{Oru}_{4}$ \\
\hline
\end{tabular}


Tablo 7. Parçalı ormanların korunmasındaki sorunlar

Table 7. Problems in the protection of fragmented forests

\begin{tabular}{|c|c|c|c|}
\hline Veri ad 1 & $\begin{array}{l}\text { Veri } \\
\text { kodu }\end{array}$ & Tema & $\begin{array}{c}\text { Tematik } \\
\text { kod }\end{array}$ \\
\hline \multirow{4}{*}{$\begin{array}{l}\text { Parçalı orman- } \\
\text { ların korunma- } \\
\text { sındaki sorun- } \\
\text { lar }\end{array}$} & \multirow{4}{*}{ Kor } & $\begin{array}{l}\text { Mera ve orman alanlarının iç içe olması nedeniyle parçalı ormanlar üze- } \\
\text { rindeki otlatma baskısı }\end{array}$ & Kor $_{1}$ \\
\hline & & $\begin{array}{l}\text { Yasa dışı yollarla parçalı ormanlardan yakacak/yapacak odun ve odun dış1 } \\
\text { orman ürünlerinin elde edilmesi }\end{array}$ & Kor $_{2}$ \\
\hline & & $\begin{array}{l}\text { Ormancılık çalışanlarının parçalı ormanları doğal hâline bırakarak koru- } \\
\text { ma tedbirlerinde gösterebileceği zafiyet }\end{array}$ & $\mathrm{Kor}_{3}$ \\
\hline & & $\begin{array}{l}\text { Parçalı ormanlardaki habitat bölünmeleri nedeniyle biyolojik çeşitliliğin } \\
\text { azalması }\end{array}$ & Kor $_{4}$ \\
\hline
\end{tabular}

Tablo 8. İlgi grubu görev dağılımı

Table 8. Titles of interest group

\begin{tabular}{lcclcc}
\hline Görevi & Adet & $\%$ & Görevi & Adet & $\%$ \\
\hline İşletme Şefi & 24 & 36,4 & Kadastro Kom. Bşk & 4 & 6,1 \\
Başmühendis & 10 & 15,2 & Mühendis & 4 & 6,1 \\
Şube Müdürü & 9 & 13,6 & Müfettiş & 1 & 1,5 \\
İşletme Müd.Yrd. & 7 & 10,6 & Bölge Müdür Yrd. & 1 & 1,5 \\
İşletme Müdürü & 6 & 9,1 & & 66 & 100 \\
\multicolumn{1}{c}{ TOPLAM } & & & & 66 \\
\hline
\end{tabular}

Tablo 9. İlgi grubu görev süresi

Table 9. Task duration of interest group

\begin{tabular}{lcclcc}
\hline Görev süresi & Adet & $\%$ & Görev süresi & Adet & $\%$ \\
\hline $1-5$ y1l & 6 & 9,1 & $16-20$ y1l & 8 & 12,1 \\
$6-10$ y1l & 11 & 16,7 & $\geq 21$ y1l & 36 & 54,5 \\
$11-15$ y1l & 5 & 7,6 & Toplam & 66 & 100 \\
\hline
\end{tabular}

\%54,4'ünün 21 y1l ve üzeri, \%16,7'sinin 6-10 y11, $\% 12,1$ 'inin $16-20$ y1l, \%9,1'inin 1-5 y1l ve \%7,6'sinın 11-15 yıl arasında olduğu belirlenmiştir (Tablo 9).

\subsubsection{Yönetim sorunlarının önem sırası}

İlgi grubunun parçalı ormanların yönetim sorunlarının önem sırasının belirlenmesi amacıyla verdikleri puanlama tablosu aşağıda verilmektedir (Tablo 10). Oransal da ğılımlar dikkate alındı ğında parçalı ormanların yönetim sorunları 2 gruba ayrılabilir:

1. Grup Sorunlar : $\operatorname{Sos}_{1}, \mathrm{Oru}_{1}, \operatorname{Kad}_{1}, \operatorname{Kad}_{2}, \mathrm{Pln}_{1}, \mathrm{Kor}_{2}$, $\mathrm{Pln}_{2}, \mathrm{Oru}_{2}$

2. Grup Sorunlar: $\mathrm{Oru}_{4}, \mathrm{Pln}_{4}, \mathrm{Kad}_{3}, \mathrm{Sos}_{3}, \mathrm{Sos}_{4}, \mathrm{Kor}_{1}$, $\mathrm{Pln}_{3}, \mathrm{Oru}_{3}, \mathrm{Sos}_{2}, \mathrm{Kor}_{3}$, Kor 4

İlgi grubunun "Parçall ormanların yönetim sorunları ile ilgili çözüm önerileriniz nelerdir?” sorusuna verdiği cevapların gruplandırılmış oransal dağılımı Tablo 11'de verilmiştir.

İlgi grubuna yönelik olarak, cinsiyete göre par- çalı ormanların yönetim sorunlarının önem sırasının değişip değişmediğine yönelik ki-kare testi uygulanmıştır. Analiz sonucunda yalnızca "cinsiyet" ile "(Oru3)" arasında \%95 güven düzeyinde istatistiksel anlamda bir ilişki tespit edilmiştir $\left(\mathrm{p}=0,022<0,05 ; \mathrm{X}^{2}=9,679\right)$.

İlgi grubunun şu anki görevi ile parçalı ormanların yönetsel sorunlarının önem sirası arasında istatistiksel anlamda bir ilişki olup olmadığı kikare testi uygulanarak analiz edilmiştir. Analiz sonucunda "şu anki görevi” ile "Korl” arasında \%95 güven düzeyinde istatistiksel anlamda bir ilişki tespit edilmiştir ( $\left.p=0,019<0,05 ; \mathrm{X}^{2}=40,503\right)$.

İlgi grubunun meslekteki çalışma yılı ile parçalı ormanların yönetsel sorunlarının önem sırası arasında istatistiksel anlamda bir ilişki olup olmadı ̆̆ 1 da ki-kare testi ile analiz edilmiştir. Buna göre "çalışma yılı" ile "Kor2" arasında \%95 güven düzeyinde istatistiksel anlamda bir ilişki tespit edilmiştir $\left(\mathrm{p}=0,024<0,05 ; \mathrm{X}^{2}=23,456\right)$. 
Tablo 10. Devlet ormanı olarak tescil edilmiş parçalı ormanların yönetim sorunları

Table 10. Management problems of fragmented forests registered as state forests

\begin{tabular}{|c|c|c|c|c|c|c|c|c|}
\hline \multirow{3}{*}{ Sorunlar } & \multicolumn{8}{|c|}{ Önem sıras1 } \\
\hline & \multicolumn{2}{|c|}{ Çok Önemli } & \multicolumn{2}{|c|}{ Önemli } & \multicolumn{2}{|c|}{ Önemsiz } & \multicolumn{2}{|c|}{ Çok Önemsiz } \\
\hline & $\begin{array}{l}\text { S1kl1k } \\
\text { (adet) }\end{array}$ & $\begin{array}{c}1 \\
(\%)\end{array}$ & $\begin{array}{l}\text { Siklik } \\
\text { (adet) }\end{array}$ & $\begin{array}{c}2 \\
(\%)\end{array}$ & $\begin{array}{l}\text { S1kl1k } \\
\text { (adet) }\end{array}$ & $\begin{array}{c}3 \\
(\%)\end{array}$ & $\begin{array}{l}\text { Siklik } \\
\text { (adet) }\end{array}$ & $\begin{array}{c}4 \\
(\%)\end{array}$ \\
\hline $\operatorname{Kad}_{1}$ & 26 & 39,4 & 25 & 37,9 & 8 & 12,1 & 7 & 10,6 \\
\hline $\mathrm{Kad}_{2}$ & 23 & 34,8 & 23 & 34,8 & 17 & 25,8 & 3 & 4,5 \\
\hline $\mathrm{Kad}_{3}$ & 9 & 13,6 & 13 & 19,7 & 32 & 48,5 & 12 & 18,2 \\
\hline $\mathrm{Kad}_{4}$ & 8 & 12,1 & 5 & 7,6 & 9 & 13,6 & 44 & 66,7 \\
\hline Toplam & 66 & 100 & 66 & 100 & 66 & 100 & 66 & 100 \\
\hline $\operatorname{Sos}_{1}$ & 35 & 53,0 & 22 & 33,3 & 3 & 4,5 & 6 & 9,1 \\
\hline $\operatorname{Sos}_{2}$ & 9 & 13,6 & 21 & 31,8 & 24 & 36,4 & 12 & 18,2 \\
\hline $\mathrm{Sos}_{3}$ & 13 & 19,7 & 9 & 13,6 & 16 & 24,2 & 28 & 42,4 \\
\hline $\mathrm{Sos}_{4}$ & 9 & 13,6 & 14 & 21,2 & 23 & 34,8 & 20 & 30,3 \\
\hline Toplam & 66 & 100 & 66 & 100 & 66 & 100 & 66 & 100 \\
\hline$P \ln _{1}$ & 26 & 39,4 & 19 & 28,8 & 16 & 24,2 & 5 & 7,6 \\
\hline $\mathrm{Pln}_{2}$ & 10 & 15,2 & 29 & 43,9 & 17 & 25,8 & 10 & 15,2 \\
\hline $\mathrm{Pln}_{3}$ & 15 & 22,7 & 11 & 16,7 & 20 & 30,3 & 20 & 30,3 \\
\hline $\mathrm{Pln}_{4}$ & 15 & 22,7 & 7 & 10,6 & 13 & 19,7 & 31 & 47,0 \\
\hline Toplam & 66 & 100 & 66 & 100 & 66 & 100 & 66 & 100 \\
\hline $\mathrm{Oru}_{1}$ & 38 & 57,6 & 14 & 21,2 & 10 & 15,2 & 4 & 6,1 \\
\hline $\mathrm{Oru}_{2}$ & 11 & 16,7 & 26 & 39,4 & 18 & 27,3 & 11 & 16,7 \\
\hline $\mathrm{Oru}_{3}$ & 12 & 18,2 & 17 & 25,8 & 23 & 34,8 & 14 & 21,2 \\
\hline $\mathrm{Oru}_{4}$ & 5 & 7,6 & 9 & 13,6 & 15 & 22,7 & 37 & 56,1 \\
\hline Toplam & 66 & 100 & 66 & 100 & 66 & 100 & 66 & 100 \\
\hline Kor $_{1}$ & 11 & 16,7 & 14 & 21,2 & 20 & 30,3 & 21 & 31,8 \\
\hline Kor $_{2}$ & 22 & 33,3 & 18 & 27,3 & 16 & 24,2 & 10 & 15,2 \\
\hline $\mathrm{Kor}_{3}$ & 11 & 16,7 & 21 & 31,8 & 21 & 31,8 & 13 & 19,7 \\
\hline Kor $_{4}$ & 22 & 33,3 & 13 & 19,7 & 9 & 13,6 & 22 & 33,3 \\
\hline Toplam & 66 & 100 & 66 & 100 & 66 & 100 & 66 & 100 \\
\hline
\end{tabular}

\subsection{Orman köylüsünün ormanlardan faydalanma durumu}

Orman köylüsüne yönelik olarak toplam 387 anket uygulaması gerçekleştirilmiştir. Ankete katılan orman köylüsünün demografik yapısının ortaya konulması amaciyla cinsiyet, yaş, meslek grubu, öğrenim durumu ile ilgili bilgiler elde edilmiştir.

Ankete katılan orman köylülerinden $\% 84,2$ ' si erkek, \%15,8'i kadındır.

Ankete katılan orman köylülerinin yaş ortalaması 47 olup en küçük katılımcı 18, en büyük katılımcı ise 80 yaşındadır.

Ankete katılanların öğrenim durumu incelendiğinde \%8,3'ünün okur-yazar, \%37'sinin ilkokul, \%26,6'sının ortaokul, \%24,3'ünün lise, \%3,9'unun üniversite mezunu olduğu belirlenmiştir.

Ankete katılanların sosyal güvencesinin olup olmadığ 1 incelendiğinde $\% 52,5$ 'inin sosyal güvencesi olduğu, \%47,5'inin ise olmadığ 1 belirlenmiştir.

Çalışma alanındaki orman köylüsünün ana geçim kaynağ1 da incelenmiştir. Buna göre orman köylüsünün \%30,5'i hayvanc1lı, \%18,6's1 tarım ve $\% 7,8$ 'i orman işçiliği alanlarında çalışırken $\% 15,5$ 'i emekli, \%10,9'u serbest meslek sahibi, \%7'si işsiz, \%3,6’sı kamu çalışanı (memur), \%4,4'ü diğer ve $\% 1,8$ 'i kadrolu işçidir.

Ankete katılan orman köylüsünün orman idaresinden zati yakacak ve yapacak ihtiyacı alıp almama durumu incelenmiş olup katılımcıların \%22'sinin yakacak, \%6,5'inin yapacak ihtiyacı aldı ğ 
Tablo 11. İlgi grubunun parçalı ormanların yönetim sorunları ile ilgili çözüm önerileri Table 11. Suggestions of the interest group on the management problems of fragmented forests

\begin{tabular}{|c|c|c|c|}
\hline Öneri & & Frekans & $\%$ \\
\hline Parçalı ormanları kullanım hakkı köy tüzel kişiliklerine verilmeli & \multirow{4}{*}{$\begin{array}{c}\text { Faydalanma } \\
(\% 46)\end{array}$} & 15 & 25 \\
\hline $\begin{array}{l}\text { Parçalı ormanlardan orman köylüsüne, köy muhtarlıklarına ya da köy koo- } \\
\text { peratiflerine kontrollü kullanım/yararlanma hakkı verilmeli }\end{array}$ & & 5 & 8 \\
\hline Parçalı ormanlar gerçek/tüzel kişiler ve vakıflar tarafından işletilmeli & & 5 & 8 \\
\hline Parçalı ormanların korunması köy tüzel kişiliklerine verilmeli & & 3 & 5 \\
\hline $\begin{array}{l}\text { Parçalı ormanlar üretim fonksiyonu dişında rekreasyon ve estetik fonksi- } \\
\text { yon gibi değerleri dikkate alınarak işletilmeli }\end{array}$ & \multirow{5}{*}{$\begin{array}{r}\text { Teknik } \\
(\% 29)\end{array}$} & 8 & 13 \\
\hline Parçalı ormanlar yetişme ortamına göre fonksiyonel olarak planlanmalı & & 1 & 2 \\
\hline Orman kadastrosu bitirilmeli & & 5 & 8 \\
\hline Parçalı ormanların yönetimi katılımcı yaklaşım ile sağlanmalı & & 2 & 3 \\
\hline Parçalı ormanlarda rehabilitasyon ve silvikültürel uygulamalar yapılmalı & & 2 & 3 \\
\hline Parçalı ormanlar sahiplilik iddiasında bulunan eski sahiplerine geri verilmeli & \multirow{5}{*}{$\begin{array}{c}\text { Mülkiyet/Özel } \\
(\% 17)\end{array}$} & 4 & 6 \\
\hline Devlet ormanlarının \%40’ı özelleştirilmeli & & 3 & 5 \\
\hline 3 ha'dan küçük alanlar orman statüsü ile orman köylüsüne geri verilmeli & & 1 & 2 \\
\hline 10 ha'dan küçük alanlar 2/B maddesi kapsamında geri verilmeli & & 1 & 2 \\
\hline Parçalı ormanların mülkiyeti vatandaşa verilmeli & & 1 & 2 \\
\hline $\begin{array}{l}\text { Kamulaştırmalarla parçalı ormanlar birleştirilerek orman bütünlüğü sağ- } \\
\text { lanmalı }\end{array}$ & \multirow{2}{*}{$\begin{array}{c}\text { Mülkiyet/Devlet } \\
(\% 8)\end{array}$} & 4 & 6 \\
\hline Devlet ormanlarının sınırlarında kesinlikle daraltma yapılmamalı & & 1 & 2 \\
\hline TOPLAM & & 61 & 100 \\
\hline
\end{tabular}

Tablo 12. Zati ihtiyaç*** almama nedenleri

Table 12. Reasons for not providing personal support to forest villagers

\begin{tabular}{lcrr}
\hline Nedeni & & Frekans & $\%$ \\
\hline Orman idaresince verilmemesi & Yönetim & 93 & 42 \\
İhale ile verilmesi & $(\% 44)$ & 5 & 2 \\
Pahalı olması ve ekonomik durumun yetersizliği & & 47 & 22 \\
Depo olmadığı için talebimizin reddedilmesi & Teknik & 7 & 3 \\
Nasıl başvuru yapacağımı bilmemem & $(\% 27)$ & 5 & 2 \\
Orman köylüsü olmamamız & & 27 & 12 \\
Orman kadastrosunun geçmemesi & Yasal & 6 & 3 \\
Kendi arazimden karşımam & $(\% 15)$ & 20 & 9 \\
İhtiyaç duymamam & Sosyal & 10 & 5 \\
TOPLAM & $(\% 14)$ & 220 & 100 \\
\hline
\end{tabular}

***: 6831 sayılı Orman Kanununun 31, 32 ve 33'üncü maddeleri kapsamına giren hak sahiplerine verilecek zati ve müşterek yapacak ve yakacak ihtiyaçlar.

\%71,6’sının ise ihtiyaç almadığı belirlenmiştir.

Orman idaresinden zati ihtiyaç almayan orman köylüsüne, ihtiyaç almama nedenleri açık uçlu soru formatında sorulmuş olup verilen cevapların gruplandırılmış listesi aşağıdaki tabloda verilmiştir (Tablo 12).

Ankete katılan orman köylüsü zati ihtiyaç almama nedeni olarak \%42 orman idaresini; \%22 pahalı olma durumunu ve \%12 orman köylüsü olmamayı göstermektedir.

Orman köylüsünün ana geçim kaynağı ile ihtiyaç alıp almama arasında istatistiksel anlamda bir ilişki tespit edilmemiştir.

Ankete katılan orman köylülerinin ormanlardan 
mantar, şifalı bitki, ot gibi odun dışı orman ürünü toplayıp toplamadıkları sorusuna cevap aranmış olup \%62'si topladıklarını, \%38'i ise toplamadıklarını ifade etmiştir.

Yukarıdaki soruya "evet" cevabını veren katılımcıların hangi amaçla ormanlardan odun dışı orman ürünü topladıkları belirlenmeye çalışılmış; \%62,9'u aile içi kullanım, \%29,6'sı hayvan yemi olarak ve \%7,5'i pazarlamak için cevabını vermiştir.

Orman köylüsünün daha önceden kullanımında ya da sahipliğinde bulunan ancak orman kadastro çalışmaları sonucunda devlet ormanı olarak tespit/ tescil edilen arazilerin olup olmadığını belirlemek için sorulan soruda katılımcıların \%50,1'i evet, \%49,9’u hayır cevabını vermiştir.

Orman köylüsünün kadastro sonucu devlet ormanı olarak tescil edilmiş arazisinin olup olmaması ile köy ormanlarından faydalanma durumu arasında istatistiksel anlamda bir ilişki olup olmadığı ki-kare testi uygulanarak analiz edilmiştir. Analiz sonucunda "kadastro sonucu devlet ormanı olarak tescil edilmiş arazinin olup olmaması" ile "köy ormanlarından faydalanma durumu" arasında \%95 güven düzeyinde istatistiksel anlamda bir ilişki tespit edilmiştir $\left(p=0.028<0.05, X^{2}=10.893\right)$.

Orman köylüsünün ormanlardan faydalanma şekillerinin de belirlendiği çalışmada faydalanma şe- killeri; \%30 ot-çalı topluyorum, $\% 27$ hayvan otlat1yorum, \%19 faydalanmiyorum, \%16 üretim olunca para ile satın alıyorum ve $\% 8$ meyve-mantar topluyorum olarak belirlenmiştir (Tablo13).

Tablo13. Ormanlardan faydalanma şekli Table 13. The forms of forest utilization

\begin{tabular}{lcc}
\hline Faydalanma şekli & Frekans & $\%$ \\
\hline Ot-çalı topluyorum & 191 & 30,0 \\
Hayvan otlatıyorum & 170 & 27,0 \\
Faydalanmiyorum & 117 & 19,0 \\
Üretim olunca para ile alıyorum & 100 & 16,0 \\
Meyve-mantar topluyorum & 52 & 8,0 \\
Toplam & 630 & 100 \\
\hline
\end{tabular}

Orman köylüsünün ana geçim kaynağı ile ormanlardan faydalanma arasında istatistiksel anlamda bir ilişki olup olmadığı ki-kare testi ile analiz edilmiştir. Analiz sonucunda ana geçim kaynağı ile köy ormanlarından faydalanma arasında \%95 güven düzeyinde istatistiksel anlamda bir ilişki tespit edilmiştir $\left(\mathrm{p}=0.004<0.05, \mathrm{X}^{2}=57.451\right)$.

Ormanlardan faydalanılması noktasında orman köylüsünün karşılaştığı sorunları belirlemek amacıyla katılımcılara açık uçlu soru yöneltilmiş, alınan cevapların gruplandırılmış listesi Tablo 14'de sunulmuştur.

Tablo14. Ormanlardan faydalanamama nedenleri

Table 14. The reasons for not being able to utilize the forest

\begin{tabular}{lcrr}
\hline Faydalanamama nedeni & & Frekans & $\%$ \\
\hline Orman idaresince verilmemesi & Yönetim & 32 & 32,4 \\
Orman muhafaza memurları ve köy bekçilerinin tutumları & 32 & 14,4 \\
Dikili satı̧̧ı (açık ihale ve tahsisli) olması & & 28 & 12,5 \\
\hline Yasal düzenlemeler ve bürokratik işlemlerin çokluğu & Yasal & 25 & 11,3 \\
Orman kadastrosu ile ormanların devlet mülkiyetine geçmesi & $(\% 23,5)$ & 18 & 8,1 \\
Orman köylüsü olmamak & & 9 & 4,1 \\
\hline Şikayet olması & Sosyal & 16 & 7,2 \\
\hline Orman yolu olmadığı için & $(\% 7,2)$ & 16 & 7,2 \\
Yeterli otlatma alanının olmayış1 & Teknik & 3 & 1,4 \\
Teleferik olmaması & $(\% 10)$ & 3 & 1,4 \\
\hline TOPLAM & & & 100 \\
\hline
\end{tabular}

Orman köylüsünün ormanlardan faydalanamama nedenleri arasında \%32,4'ü orman idaresi vermiyor, \%14,4'ü orman muhafaza memurları ve köy bekçilerinin tutumları, \%12,6'sı dikili satışın olması, \%11,3'ü yasal düzenlemeler ve bürokratik işlemlerin çokluğu seçenekleri yer almaktadır.
Ankete katılanlardan ormanlardan faydalanabilmeleri noktasında neler yapılması gerektiğiyle ilgili olarak önerilerde bulunmaları istenmiş, alınan cevapların gruplandırılmış listesi Tablo 15 'de sunulmuştur. 
Tablo 15. Ormanlardan faydalanabilme önerileri

Table 15. Suggestions for utilization of the forests

\begin{tabular}{|c|c|c|c|}
\hline Öneri & & Frekans & $\%$ \\
\hline Yakacak ve yapacak ihtiyacın verilmesi & \multirow{10}{*}{$\begin{array}{c}\text { Faydalanma } \\
(\% 58)\end{array}$} & 61 & 19 \\
\hline Olağanüstü kesimler ve zati ihtiyacın köylüye bedelsiz verilmesi & & 45 & 14 \\
\hline Devlet ormanlarının kullanım hakkının köylüye verilmesi & & 18 & 5 \\
\hline Dikili satış işlemlerinin kolaylaştırılması, her zaman ihale olmaması & & 23 & 7 \\
\hline Bal ormanlarının kurulması & & 15 & 4 \\
\hline Hayvancılık desteklenerek, otlatma alanlarının düzenlenmesi & & 12 & 4 \\
\hline Üretim işlerinde muhtarlara yetki verilmesi & & 6 & 2 \\
\hline Köy halkı dışındaki kişilere üretim yaptırılmaması & & 2 & 1 \\
\hline Köy ormanlarından baltalık ayrılması & & 3 & 1 \\
\hline Üretim işleri köylüye yaptırılması & & 2 & 1 \\
\hline Kadastro sonucu alınan orman alanlarının köylüye geri verilmesi & \multirow{3}{*}{$\begin{array}{c}\text { Mülkiyet } \\
(\% 20)\end{array}$} & 34 & 10 \\
\hline Orman arazilerinin halka verilmesi & & 25 & 8 \\
\hline 6831/2B maddesinin uygulanarak arazilerin geri verilmesi & & 8 & 2 \\
\hline Orman köylüsü olma & \multirow{2}{*}{$\begin{array}{l}\text { Yasal } \\
(\% 10) \\
\end{array}$} & 22 & 7 \\
\hline Kz ve Ks'nin orman ağacı vasfından çıkarılması & & 9 & 3 \\
\hline Orman yollarının yapılmas1 & \multirow{3}{*}{$\begin{array}{l}\text { Teknik } \\
(\% 12)\end{array}$} & 21 & 6 \\
\hline Gençleştirme ve bakım çalışmalarının yapılması & & 12 & 4 \\
\hline Köylüye eğitim verilmesi & & 6 & 2 \\
\hline TOPLAM & & 324 & 100 \\
\hline
\end{tabular}

\section{Tartışma ve Sonuçlar}

Bu çalışma ile Trabzon Orman İşletme Müdürlüğü örneğinde parçalı ormanların yönetim sorunları değerlendirilmiştir. Bu kapsamda, orman kaynaklarını yönetenlerin uygulamada karşılaştıkları teknik ve sosyal sorunlar tespit edilmiş, orman kaynakları ile iç içe yaşayan orman köylüsünün orman kaynaklarını kullanma durumu, beklentileri ve önerileri değerlendirilmiştir.

Parçalı ormanların yönetim sorunlarıyla ilgili beş ana sorun belirlenmiştir. Bunlar; parçalı ormanlarin kadastrosunun yapılmasındaki sorunlar (Kad), parçalı ormanların yönetimindeki sosyal sorunlar (Sos), parçalı ormanların planlanması aşamasındaki sorunlar (Pln), parçalı ormanlardaki ormancılık uygulamaları (koruma, ağaçlandırma, bakım, rehabilite vb.) açısından sorunlar (Oru) ve parçalı ormanların korunmasındaki sorunlardır (Kor). Bu beş ana sorun kendi içinde dörde ayrılmaktadır ve toplamda 20 soruna işaret etmektedir. Bu sorunlar oransal dağılımlarına göre 2 gruba ayrılmıștır:

1. Grup Sorunlar: $\operatorname{Sos}_{1}, \mathrm{Oru}_{1}, \operatorname{Kad}_{1} \operatorname{Kad}_{2}, \operatorname{Pln}_{1}, \mathrm{Kor}_{2}$, $\mathrm{Pln}_{2}, \mathrm{Oru}_{2}, \mathrm{Kor}_{4}$

2. Grup Sorunlar: $\mathrm{Kad}_{4}, \mathrm{Oru}_{4}, \mathrm{Pln}_{4}, \mathrm{Kad}_{3}, \mathrm{Sos}_{3}, \mathrm{Sos}_{4}$, $\mathrm{Kor}_{1,} \mathrm{Pln}_{3}, \mathrm{Oru}_{3}, \mathrm{Sos}_{2}, \mathrm{Kor}_{3}$, Kor $_{4}$
1. grup sorunlar arasında, orman kaynaklarını yönetenler, orman vasfının ve mülkiyetinin belirlenmesini $\left(\mathrm{Kad}_{1}-\mathrm{Kad}_{2}\right)$ parçalı ormanların yönetimiyle ilgili önemli bir sorun olarak görmektedirler. $\mathrm{Bu}$ duruma paralel olarak kesinleşmiș orman kadastrosuna rağmen parçalı ormanlar üzerinde sahiplilik iddialarının devam etmesi $\left(\mathrm{Sos}_{1}\right)$ sosyal sorunlar arasında önemli bir yere sahiptir. Ayaz (2004) ve Ayaz ve Alkan (2009) tarafindan çalışılan bölgede yapılmış araştırmalarda da orman köylülerinin kadastro sunucu devlet ormanı olarak tescil edilmiş yerlerden yararlanmalarının sürdüğünü tespit etmişlerdir. Parçalı ormanların fonksiyonlarına ve işletme amaçlarına karar verilmesindeki zorluklar $\left(\mathrm{Pln}_{2}\right)$ ile bu ormanlarda yap1lacak olan silvikültürel uygulamalarda karşılaşılan sorunlar $\left(\mathrm{Oru}_{1}-\mathrm{Oru}_{2}\right)$, orman kaynaklarını yönetenler açısından önemli bulunmuştur. Bölgedeki parçalı ormanlarda planlı bir ormancılık yapılmasının mümkün olamayacağı yönünde görüş belirten çalışmalar da bulunmaktadır (Ayaz ve Gümüş, 2016). Ormanların korunması noktasında, orman kaynaklarını yönetenler yasa dışı yollarla ormanlardan faydalanma konusunu önemli bir sorun olarak değerlendirmektedirler (Kor ${ }_{2}$ ).Orman kaynaklarını yönetenler, habitat bölünmeleri nedeniyle biyolojik çeşitliliğin azalmasını (Kor ${ }_{4}$ ) hem 1 . grup hem de 2 . grup sorun olarak değerlendirmektedirler. Orman 
kaynaklarının planlanması aşamasında kadastro altlıklarının kullanılmamasından kaynaklanan sorunlar $\left(P \ln _{1}\right)$, parçalı ormanların yönetim sorunları arasında önemli görülmektedir.

2. grup sorunlar arasında, orman kadastro komisyonlarının parçalı ormanları özel orman vasfı ile tespit edememesi $\left(\mathrm{Kad}_{3}\right)$ ve 2/B madde uygulamaları ile ormanların daha parçalı hâle gelmesi $\left(\mathrm{Kad}_{4}\right)$ kadastro ile ilgili sorunların bir bölümünü oluşturmaktadır. Bireysel ya da toplu olarak vatandaşın parçalı ormanlardan yapılacak ormancılık uygulamalarına (bakım, gençleştirme, rehabilitasyon, üretim vb.) engel olması ( $\left.\operatorname{Sos}_{2}\right)$, mevzuatın değişeceği ve mülkiyetinin vatandaşa geçeceği beklentisiyle parçalı ormanların tahrip edilmesi $\left(\mathrm{Sos}_{3}\right)$, yöreye özgü geleneksel orman ve ormancılık algısından dolayı, parçalı ormanların orman köylüsü tarafından orman olarak algılanmaması $\left(\mathrm{Sos}_{4}\right)$ sorunları 2. grup sorunlar arasında değerlendirilmektedir. Plan kararlarının yöre halkı ve diğer paydaşların katılımıyla verilmesindeki zorluklar $\left(\mathrm{Pln}_{3}\right)$ ve parçalı ormanların envanterinin yapılmasındaki zorluklar $\left(\mathrm{Pln}_{4}\right)$, planlamayla ilgili 2. grup sorunları oluşturmaktadır. Ormanc1lık uygulamalarıyla ilgili 2. grup sorunlar; küçük alanlarda çalışmanın ekonomik olmayacağı düşüncesiyle, parçalı ormanların rehabilitasyon çalışmalarına dâhil edilmemesi $\left(\mathrm{Oru}_{3}\right)$, parçalı ormanlara; devrik, kırık, böcek zararı gibi biyotik ve abiyotik faktörlerden kaynaklanan olağanüstü durumlarda bakım yapılamaması $\left(\mathrm{Oru}_{4}\right)$ olmuştur. Ormancılık çalışanlarının parçalı ormanları doğal hâline bırakarak koruma tedbirlerinde gösterebileceği zafiyet $\left(\right.$ Kor $\left._{3}\right)$, parçalı ormanlardaki habitat bölünmeleri nedeniyle biyolojik çeşitliliğin azalması $\left(\mathrm{Kor}_{4}\right)$ koruma açısından 2. grup sorunları oluşturmaktadır.

İlgi grubuna yönelik yapılan ankette, erkek kat1lımcıların, kadın katılımcılara göre "küçük alanlarda çalışmanın ekonomik olmayacağı düşüncesinden hareketle parçalı ormanların rehabilitasyon çalışmalarına dâhil edilmemesi” sorununu daha önemsiz buldukları söylenebilir.

İlgi grubunun şu anki görevi ile parçalı ormanların yönetsel sorunlarının önem sırası değerlendirildiğinde, şu anki görevi işletme şefi ve mühendis olanların "mera ve orman alanlarının iç içe olması nedeniyle parçalı ormanlar üzerinde otlatma baskısının olması" sorununu daha önemsiz buldukları söylenebilir.

İlgi grubunun meslekteki çalışma yılı ile parçalı ormanların yönetsel sorunlarının önem sırası incelendiğinde, diğer çalışma yıllarına göre çalışma yılı 20 ve üzerinde olan katılımcıların "yasa dışı yollarla ormanlardan odun ve odun dişı orman ürünlerinin elde edilmesi” sorununu daha önemli buldukları söylenebilir.

İlgi grubunda yer alan orman mühendisleri parçalı ormanların yönetimiyle ilgili olarak en deneyimli uzmanlardır. $\mathrm{Bu}$ ormanların nasıl ve hangi amaçlarla yönetilmesinin daha yararlı olacağını en iyi şekilde değerlendirebilecek birikime sahiptirler. Orman kaynaklarını yönetenlerin parçalı ormanların yönetim sorununu çözümü konusunda ilgi çekici önerilerde bulunmuşlardır. Öneriler genel olarak orman köylüsüne faydalanma hakkının verilmesi (\%46); planlama, silvikültür, kadastro gibi teknik konular (\%29), özel orman mülkiyeti (\%17) ve devlet orman mülkiyeti (\%8) şeklindedir. Burada ortaya çıkan en önemli nokta, orman kaynaklarını yönetenlerin parçalı ormanların yönetiminde devlet orman işletmeciliğini alternatif bir çözüm olarak görmemesidir. Kanaatimizce parçalı ormanların nasıl yönetilmesi gerektiği konusunda ormancı teknik personelinin yaptığı değerlendirmeler çok önemli olup dikkatle incelenmelidir.

İlgi grubunda yer alan orman kaynakları yöneticilerinin önemli bir bölümü (\%46) parçalı ormanlar ile köy tüzel kişilikleri arasında ilişki kurmuştur. Mülkiyeti devlette kalmak üzere yararlanma hakkının muhtarlıklara / köy tüzel kişiliklerine / kooperatiflere / vakıflara bırakılmasını önermektedirler. Bu öneri, üzerinde dikkatle durulması gereken bir değerlendirmedir. Mülkiyetin devlette olması ya da olmaması bu bakımdan çok da önemli değildir. Bu nedenle yararlanma hakkı üzerinde yoğunlaşmak daha yararlı olacaktır. Bu çerçevede ülkemiz koşullarında orman kaynakları - köy tüzel kişilikleri ilişkileri ülkemiz geleneksel orman mülkiyeti ya da kullanımı ilişkileri açısından uygun görülmektedir. Nitekim orman kanununda da bu ilişkiler dikkate alınmış ve orman kaynakları yönetimiyle "köy tüzel kişilikleri ve kooperatifler" sıklıkla ilişkilendirilmiştir.

Öte yandan Gümüş ve ark. (1998) ile Diktaş (2003) tarafından yapılan araştırmalarda da köy tüzel kişiliklerinin orman kaynaklarını yönetmesiyle ilgili bazı güzel örneklerin varlığı ortaya konulmuştur.

İlgi grubu uzmanlarından 3'ü (\%5) ormanların yüzde 40'ının özelleştirilmesi gerektiğini ifade etmiş̧lerdir. Bu öneri çalışma konusu ile doğrudan ilgili olmadığı için değerlendirme dışında tutulmuştur. Bu çok farklı tartışmaları içerecek bir konudur. Ayrıca anayasaya göre olanaklı değildir. Anayasaya uygun olsa bile ülkemiz koşullarında yararlı sonuçlar vereceğini ortaya koyan somut veriler ya da araştırmalar da yoktur.

İlgi grubunda yer alan uzmanlardan 4'ü parçalı, 
1'i 3 hektardan küçük, 1'i de 2/B kapsamında olmak üzere toplam 6'sı (\%10) bu tip ormanların sahiplerine geri verilmesi gerektiği görüşünü öne sürmüştür. Oysa bu alanlar önceden de devlete ait olup bir şahıstan alınmamıştır. "Sahiplerine geri verilmelidir" önermesi uygun değildir. Bu alanların sahibi eskiden beri devlettir ve devletleştirilen alanlar olamazlar. Eskiden bir sahibi olsayd 3 hektardan küçük olanlar Orman Kanunu'na (6831 s.y. 1. madde g bendi) göre orman sayılmazlard1. 3 hektardan büyük olanlar da diğer devlet ormanlarından bağımsız oldukları için 4785 sayılı Yasa ile devletleştirilmiş olsalar bile 5658 sayılı Yasa ile iade edilmiş olurlardı. Bu nedenle bu önerileri dikkate almak yanıltıcı olacaktır. Bu kapsamda ilgi grubunun sadece bir elamanı "parçalı ormanların mülkiyetinin köylülere verilmesini" önermektedir, denilebilir. Sonuçta bu ormanların eski sahibi yoktur. Bu nedenle eski sahiplerine iade edilmesi gibi bir değerlendirme yapılamaz. Buraların kişilere verilmesi de başta sosyal/sosyolojik, geleneksel orman mülkiyet anlayışı ya da anayasaya uygun olmamak gibi birçok nedenle çok olanaklı ya da rasyonel görülmemektedir. Ayrıca kişilere verilmesi durumunda bunun ulusal ormanc1lik politikası amaçlarına (ormanların korunması ve geliştirilmesi, orman köylülerinin kalkındırılması gibi) ulaşmak konusunda etkili olup olmayacağ1 somut bir biçimde ortaya konulmamıştır.

Ankete katılan orman köylülerinin \%71,6'sı orman idaresinden zati yakacak ve yapacak ihtiyacı almamaktadırlar. Orman köylüsünün ihtiyaç alamama nedeni olarak çoğunlukla orman idaresinin vermemesi ve yasal düzenlemeler, ekonomik olmaması ve orman köylüsü olunmamasından kaynaklandığ 1 belirlenmiştir. Orman idaresi, zati yakacak/yapacak ihtiyaç taleplerini orman deposu olmadığından tahsisli dikili satışla karşılama yoluna gitmektedir. Tahsisli satışlarda teminat yatırılması, bürokratik işlemlerin fazla olması, orman emvalinin ormandan çıkarılmasındaki zorluklar gibi nedenlerle orman köylüsünce tercih edilmemektedir. Nitekim benzer bir sonuç Alkan ve Şahin'in (2011) çalışmasında da belirlenmiş olup orman köylüsünün dikili satış uygulamasına bakış açısının \%63,2 oranında olumsuz olduğu tespit edilmiştir.

Ankete katılan orman köylülerinin \%62'si ormanlardan odun dışı orman ürünü toplamaktadır ve toplanan ürünlerin büyük çoğunluğu aile içinde tüketilmekte veya hayvan yemi olarak kullanılmaktadır. Pazarlama amacıyla mantar, şifalı bitki vb. toplayanların oranı ise çok düşük seviyededir.

Daha önceden kullanımında ya da sahipliğinde bulunan ancak orman kadastro çalışmaları sonucunda devlet ormanı olarak tespit/tescil edilmiş arazi- leri olan orman köylüsünün oran1 \%50,1'dir. Devlet ormanı olarak tescil edilmiş arazisi olmayanların oran1 ise \%49,9'dur. Doğu Karadeniz Bölgesi’nin tamamında 2002 yılında yapılmış bir çalışmada da kadastro sonucu devlet mülkü olarak tespit edilmiş arazisi bulunduğunu belirtenlerin oranı \%49,7'dir (Ayaz, 2004). Devlet ormanı olarak tescil edilmiş arazisi olan orman köylüsünün, ormanlardan faydalanma konusunda devlet ormanı olarak tescil edilmiş arazisi olmayanlara göre daha aktif olduklar1 söylenebilir.

Orman köylülerinin ormanlardan faydalanma durumu değerlendirildiğinde, ana geçim kaynağı tarım, hayvancılık olan ve emekli maaşı olan orman köylüsünün ormanlardan odun dışı orman ürünü toplayarak ve hayvan otlatarak daha çok yararlandığ 1 , memur ve kadrolu işçilerin ise daha az faydalandığı söylenebilir.

Ankete katılan orman köylüleri, ormanlardan faydalanamama nedenini yönetim kaynaklı $(\% 59,3)$ görmektedir. Orman idaresinin, orman köylüsünün orman ürünlerine olan ihtiyacını tahsisli/açık artırmalı dikili ağaç satışı yöntemiyle karşılama yoluna gitmesi, orman köylüsü tarafından sorun olarak algılanmaktadır. Gerek zati ihtiyaç alımlarında gerek ormanlardan faydalanma noktasında "idare vermiyor” şeklinde bir alg1 söz konusudur.

Ankete katılan orman köylüsünün ormanlardan faydalanabilme önerisi, orman ürünlerine yönelik ihtiyaçlarının karşılanması (üretim amaçlı) şeklindedir.

Kadastro çalışmaları tamamlandıktan sonra, artık bölgedeki geleneksel mülkiyet anlayışı ve sahiplilik iddiaları yerini bu ormanlardan faydalanmanın yasal yollarını bulma arayışına bırakmıştır. Nitekim parçalı ormanlardan, kaynağa zarar verilmeden yerel halkın yararlanması olanağının sağlanmasını öneren çalışmalar da bulunmaktadır (Ayaz ve Gümüş, 2016).

Orman kaynaklarını kullananlar da, bu kaynaklarla iç içe olanlar da artık orman köylülerine kullanım hakkının verilmesi amacıyla yasal düzenlemelerin yapılması konusunda hemfikirdirler.

Ormanların giderek daha küçük parçalara bölünmesi Amerika Birleşik Devletleri’nde, özellikle de özel mülkiyetin daha yoğun olduğu Güzey bölümünde de önemli bir sorundur. Sharitz ve ark. (1992) tarafindan yapılan bir çalışmada habitat parçalanması ile biyolojik çeşitliliğin korunması, su havzası ve su kalitesinin korunması ve bölgesel arazilerin değerlendirilmesi, orman ekosistemlerinin bütünlüğü ve ormanlarda verim düşüklüğünün oluşması gibi birçok sorunun ortaya çıktığına işaret edilmekte ve 
orman ekosisteminin sürdürülebilirliğini sağlamak için ekolojik ilkelerle bütünleşik bir doğal kaynak yönetiminin gereği üzerinde durulmaktadır.

$\mathrm{Bu}$ çalışma ile parçalı ormanların yönetimi konusunda orman köylüleriyle birlikte hareket edilmesinin gerekli olduğu ortaya çıkmıştır. Köylerin sosyolojik yapısı da dikkate alınarak bu alanların, köylülerin ortak ihtiyaçlarının (ekonomik/ekolojik) karşılanmasında öncelikli olarak yönetilmesi gerekmektedir. Böylece küçük de olsa bu alanların yönetimi ülkemiz ekonomisine katkı sağlayabilecektir. Ayrıca köylülere moral etkisinin de olacağ düşünülebilir.

Bu çalışma ile elde edilen veri ve değerlendirmeler, parçalı ormanlara orman amenajman planı içerisinde farklı bir statü kazandırılarak faydalanmanın yerel yönetimlere bırakılmasının uygun olabileceğini göstermektedir. Aslında bu değerlendirme, orman köylülerinin bu türden ormanların yönetimine ve işletilmesine yönelik beklentileriyle de uyumludur.

\section{Teşekkür}

Bu makale Orman Genel Müdürlüğü, Doğu Karadeniz Ormancılık Araştırma Enstitüsü Müdürlüğü bünyesindeki “Ormanların Parçalılık Durumu ve Parçalı Ormanların Yönetim Sorunlarl (Trabzon Orman Işletme Müdürlüğ̈̈ Örneği)’'adlı projenin, OGM Araştırma İhtisas Grupları toplantısında yayımlanması yönünde karar verilen proje sonuç raporunun bir bölümünü kapsamaktadır. Çalışmaya verdikleri katkılardan dolayı Trabzon Orman Bölge Müdürlüğü personeline ve yöredeki orman köylülerine teşekkürlerimizi sunarız.

\section{Kaynaklar}

Andren, H., 1994. Effects of habitat fragmentation on birds and mammals in landscapes with different proportions of suitable habitat: A review, Oikos, 71(3), 355-366.

Alkan, S., Şahin, H.A., 2011. Doğu Karadeniz Bölgesi'nde dikili satış uygulamaları konusunda ilgi gruplarının görüşleri, DKOAEM, Yayın No: 34, T.Bülten No: 25 , Trabzon.

Anonim, 2012. Resmi Gazete, Say1:28489, Tarih: 06/12/2012, Ankara.

Anonim, 2016. Trabzon Orman İşletme Müdürlüğü 2016 yılı çalışma programı, Trabzon.

Arslanoğlu, İ., 2016. Bilimsel yöntem ve araştırma teknikleri, 222 s., Ankara.

Ayaz, H., 2004.Türkiye ormancılığında 4785 sayılı Yasa'nın uygulanması ve sonuçları üzerine bir araştırma (Doğu Karadeniz Bölgesi örneği), KTÜ Fen Bilimleri
Enstitüsü, yayınlanmamış doktora tezi, 163 s., Trabzon.

Ayaz, H., Alkan, S., 2009. 5304 sayılı Yasa'ya göre yapılan orman kadastrosu uygulamalarının taraflarınca değerlendirilmesi, Ormancilıkta Sosyo-Ekonomik Sorunlar Kongresi, bildiriler kitab1, 216-224, Isparta.

Ayaz, H., Gümüş, C., 2016. Türkiye'de orman mülkiyeti, yaşanan sorunlar ve çözüm önerileri, Karadeniz Araştırmaları Enstitüsü Dergisi, ISSN: 2458-7680, EISSN: 2458-9705, KTÜ Matbaas1, 2(2), 212-236, Trabzon.

Bozgeyikli, H., 2013. Bilimsel araştırma yöntemleri, www.egitim.erciyes.edu.tr/hbozgeyikli/sunular/arsyon. Ppt. (Erişim tarihi: 08/06/2015)

Coşkun Hepcan, Ç., 2008. Doğa korumada sürdürülebilir bir yaklaşım, ekolojik ağların belirlenmesi ve planlanması: Çevre-Urla Yarımadası örneği, Ege Üniversitesi Fen Bilimleri Enstitüsü, Doktora Tezi, İzmir.

Çıng1, H., 1994. Örnekleme kuram1, Hacettepe Üniversitesi Fen Fakültesi Yayınları, Ders Kitapları Dizisi 20, Ankara.

Daşdemir, İ., 2016. Bilimsel araştırma yöntemleri, Nobel Akademik Yayıncılık ve Danışmanlık Tic.Ltd.Şti., Y.No: 1536, ISBN: 978-605-320-442-8, 201 s., Ankara.

Deniz, B., Küçükerbaş, E.V., Eşbah Tunçay, H., 2006. Peyzaj ekolojisine bakış, ADÜ Ziraat Fakültesi Dergisi, 3 (2): 5-18.

Diktaş, N., 2003. Türkiye ormancılığında Baraklı modeli, İ̈̈ Orman Fakültesi Dergisi, Seri:B, 52-53(2), 125-138.

Fahrig L.. 2003. Effects of habitat fragmentation on biodiversity. Annual Review of Ecology Evolution and Systematics, 34, 487-515.

Foley, J.A., DeFries, R., Asner, G.P., Barford, C., Bonan, G., Carpenter, S.R., Chapin, F.S., Coe, M.T., Daily, G.C., Gibbs, H.K., Helkowski, J.H., Holloway, T., Howard, E.A., Kucharik, C.J., Monfreda, C., Patz, J.A., Prentice, I.C., Ramankutty, N., Snyder, P.K.., 2005. Global consequences of land use, Science, v: 309, Issue: 5734, $570-574$

Gümüş, C., Ayaz, H., Batı, M., Hacıhasanoğlu, S.,1998. Türkiye de köy ormancılığı uygulamaları, Cumhuriyetimizin 75. Yılında Ormancılığımız Sempozyumu, Bildiri Kitabı, 68-77.

Odum, E.P., Barrett, G.V., 2005. Fundamentals of ecology. Thomson - Brooks/Cole. Belmont, Ca., 598 s.

Orhunbilge, A., N., 2000. Örnekleme yöntemleri ve hipotez testleri (Gözden geçirilmiş ve genişletilmiş 2 . Bask1, ISBN: 978-9758345045, Avc1ol Basım ve Yayın, 420 s., İstanbul.

Sharitz, R.R.,Boring, L.R., Van Lear, D.H., Pinder,J.E., 1992. Integrating ecological concepts with natural re- 
source management of Southern Forests, Ecological Applications, 2(3), 226-237.

Sala, O.E., Chapin, F.S., Armesto, J.J., Berlow, E., Bloomfield, J., Dirzo, R., Huber-Sanwald, E., Huenneke, L.F., Jackson, R.B., Kinzig, A., Leemans, R., Lodge, D.M., Mooney, H.A., Oesterheld, M., Poff, N.L., Sykes, M.T., Walker, B.H., Walker, M. \& Wall, D.H., 2000. Global biodiversity scenarios for the year 2100, Science, 287, 1770-1774.

Wilcove, D.S., McLellan, C.H., Dobson, A.P., 1986. Habitat fragmentation in the temperate zone, Conservation Biology, 6, 237-256.
Williams, J.C., Snyder, S.A., 2005. Restoring habitat corridors in fragmented landscapes using optimization and percolation models, Environmental Modeling \& Assessment, 10(3), 239-250.

Yachkaschi, A., Adeli K., Latif H., Mohammadi S.K., Seifollahian, M., 2008. Trends in forest ownership, forest resources tenure and institutional arrangements: Are they contributing to better forest management and poverty reduction? A case study from the Islamic Republic of Iran, Technical Report.

Young, A., Boyle,T., Brown, T., 1996. The population genetic consequences of habitat fragmentation for plants, Trends in Ecology and Evolution, 11(10), 413-418. 